\title{
Film, Law and Propaganda Preliminary Remarks on Law and Film Relations at the Beginning of Communist Poland
}

\begin{abstract}
After World War II in Central and Eastern Europe cinema and literature were harnessed in the construction of a new order (as earlier in the USSR). Contrary to traditional belief, it was built not only on violence. Ideology played a fundamental role in the escape from postwar nihilism and convinced many intellectuals to join building the "better world". The propaganda was supposed to effectively influence the minds of those who did not understand the laws of historical necessity. Law-making and the making of cultural texts were tied together in an unprecedented way. Which results did it bring to cinematography? How did the law and cultural texts present the new order? Which conclusions remain relevant from that lesson of "making things legal"?
\end{abstract}

\section{Introduction}

Studies on the relationship between history and film commenced many years ago. ${ }^{1}$ It is therefore surprising to see that so far there is only an insignificant presence of the history of law research on the field of studies. ${ }^{2}$

A few years ago the American textbooks were published $^{3}$ (and even the first collection of articles in Polish ${ }^{4}$ ). Seeing how researchers discussed older American films, subjecting them to the analysis of the law in film content, one could say that generally speaking the European history of law can have a good chance of development in this field of studies.

Therefore it seems that nothing stands in the way to make a similar effort with respect to the cinematographic works from Central and Eastern Europe. For example law and film links as

\footnotetext{
${ }^{1}$ See for example: KURZ, Film i historia; CARNES, Past Imperfect; ROSENSTONE, History on Film.

2 See: MACHURA, ROBSON, Law and Film.

${ }^{3}$ Asimow, MAder, Law and Popular Culture.

${ }^{4}$ GrabarczyK, Stempowski, Prawo w filmie.
}

presented in the communist propaganda works seem to be relatively easy to detect and worthy of careful examination. The communist propaganda defined an official common goal for all human activities. In my article I would like to examine two films ("Forbidden Songs" and "The Border Street") from a peculiar period of time: although the Third Reich had been defeated, still the political fight for the power was being conducted. The Second World War had unprecedented social consequences that had to be to some extend reflected on the movie screens. "The Poles were a broken society, devoid of elites and institutions, moving in all directions as never before in history. They were more like' a porridge society ' - the mass of the tribal communities of family character - rather than a normal society". ${ }^{5}$

In these abnormal conditions the communist authorities tried to gain some popularity, while conducting a coldblooded political fight with their enemies. For cinematography this meant

${ }^{5}$ ZAREMBA, Wielka Trwoga 140. 
that the rigid criteria of socialistic realism were not officially imposed on Polish culture before the end of the 1940s.

For that reason in the first post-war films the new ideology was presented to some extent in a diplomatic way. The pure Stalinism in cinema formally started in 1949 after the congress of filmmakers in Wisła. ${ }^{6}$ The congress enforced the doctrine of socialist realism. Afterwards this relative freedom of movie making had been limited by the ideological criteria (for example the way the cinematographic censorship worked drastically changed 7 ).

Until 1949 in cinematographic works one can see a dramatic effort to create a new language to speak about the tragic past and to foretell the optimistic future. Within these frames we can try to analyze "law in film" content through fragments of films or even through some chosen film sequences.

\section{1.}

The first cinematographic work ("Forbidden Songs", 1946, director: Leonhard Buczkowski) in communist Poland turned out to be a breakthrough: it influenced the imagination of Polish viewers on a massive scale. The box office success was unbelievable: during 20 years the film was seen by about 14 million people. ${ }^{8}$ At the same time the film met with severe criticism, which led not only to its withdrawal from distribution, but also to changes to the original version. The film was considered to be very far from the fulfillment of ideological expectations. In short, according to the contemporary critics,

\footnotetext{
${ }^{6}$ A small town in southern Poland. As to the congress, see: MADEJ, Zjazd filmowy w Wiśle.

${ }^{7}$ MisiaK, Cenzura filmowa. Cf. ZWIERZCHOWSKI, Zapomniani bohaterowie.

${ }^{8}$ Attendance 31. 12. 1971: Mały Rocznik Filmowy 133 (cited in: ToEPLITZ, Historia filmu polskiego 425).
}

"Forbidden Songs" flattered to cheap tastes rather than shaping them to aspiring to some kind of so-called 'high culture'. 9

The film plot was uncomplicated. In a film studio film workers recall the tunes and songs from the time of German occupation that were supposed 'to uplift hearts' of the population in the conquered and occupied country. The intrigue of the story was located in Warsaw and by and large extended from the outbreak of WW II to the Warsaw uprising (1944). The story was largely manipulated by some historical omissions (for example there were no references to the dramatic Soviet attack on Poland in 1939 or to the ambiguous role of the Soviet army during the Warsaw uprising that in fact helped the Germans to crush the Polish Underground Army) and the pompous propaganda ending (a glorification of the First Polish Army subordinated to the Soviet Union).

At the same time "Forbidden Songs" surprises us even in the present day by the fact of multiplying references to the execution of justice and to the construction of the alternative legal order (or simply to the iconography referring to the law and justice).

In the story one can find for example such elements as: judicial executions done by special courts on behalf of the Polish Underground State; seizure of the monopoly of what is legal by the Nazis and therefore the necessity to create an alternative legal order; results of the functioning of legal instruments leading to the Shoah. ${ }^{10}$ Eventually the title of the movie, referring to the "little sabotage" actions, demands a short comment.

"The juxtaposition of these two, seemingly opposing concepts, the legislation and the crime, may seem at first glance a paradox" - wrote

\footnotetext{
${ }^{9}$ In extenso cf.: MADEJ, Kino.

${ }^{10}$ A subject that would be developed by "The Border Street" movie.
} 
Kazimierz Kolańczyk in the first volume of the Bulletin of the Central Commission for the Investigation of German Crimes in Poland. ${ }^{11}$ In principle the film vision of the Third Reich law in force does not differ from the well-established opinion in Polish legal history. It is clearly expressed in a popular manual by a sentence: "The German law, which was applied to the Poles, was essentially lawless." 12 It refers us to many theoretical approaches to Nazi law that were created after WW II, including the concept of statutory lawlessness by Gustav Radbruch.

At the same time, Polish lawyer, Wacław Jastrzębowski recalled that the structure of legal norms and practice of the Nazi state had not provided to habitants of the occupied countries any legal protection against an abuse of power. In fact the concept of the abuse of power in general ceased to have any content. ${ }^{13}$

After the war, courts were taking into account the concept of "unlawfulness". For example in 1948 the Supreme Court stated in one of its decisions that the mere unlawfulness of Nazi law meant the lack of any binding force of the whole law imposed by the invaders. ${ }^{14}$

Legal historians develop this idea referring to the acts of legislation in force at that time (including the acts of legislation of the Polish Underground State that was legally considered as a continuity of the $2^{\text {nd }}$ Republic of Poland). Filmmakers were seeking their own means of

\footnotetext{
${ }^{11}$ KolańCZYK, Prawo niemieckie 279.

12 BARDACH, LeŚNODORSKI, PIETRZAK, Historia ustroju 586.

${ }^{13}$ JASTRZĘBOWSKI, Rządy niemieckiego okupanta 3.

${ }^{14}$ Decision of the civil division of the supreme court (C. 935/48). The supreme court decided: "Contracts regarding the conferment of freehold property, which were concluded in Poland during Hitler's regime between 1939 dan 1945 in writing without the requirement of a notary deed, are not void, only if the adherence to the formal requirement was not possible due to reasons which result from the illicit activities of the occupying forces" (Demokratyczny Przegląd Prawniczy 1949/6-7, 103-104).
}

expression - incidentally - reflecting the image of Polish legal culture of the WW II period. Let us examine a few examples.

After the experience of the law-making by the totalitarian regimes, in jurisprudence the thesis of legal positivism, unconditionally recognizing the legal norms made by state authorities, was rejected. However under the Nazi occupation, the film reminds the audience, the phenomenon of living under statutory lawlessness was profoundly experienced by the population of the defeated country, even before the theoretical concept was created. Moreover, the fight with the German occupiers had to be conducted according to the rules of the underground state law. This law however lacked one feature of normal legislation - its public disclosure. The film reminds us that on an everyday basis it remained imperceptible. Spectacular actions such as public executions of traitors by the underground army might have served as a visible exception to the occupational rules. In "Forbidden Songs" in terms of that subject viewers were not openly manipulated, but the accents of presenting the public execution phenomenon were relocated in an interesting way.

In the first released post-war film these executions appeared twice. One scene could be considered as an official execution. The viewers can see that two men come to a woman who was sentenced to death by the underground court, read something from the paper and shots are fired from guns - all drowned out by the loud music of the cooperating yard orchestra. Another scene of execution concerns a secret collaborator of the Geheime Staatspolizei, who is shot publicly in the street. For the audience to have no doubt about the guilt of the person who was executed, filmmakers made close-ups showing a document written in German. The document clearly attested the cooperation with the German secret police.

The first scene of execution was met with devastating critique by one of the main representa- 
tives of the new regime. Besides the esthetic comments, Adam Ważyk wrote that only a clear presentation of the woman as a German agent could have justified such a penalty. ${ }^{15}$ In fact Ważyk was wrong. For example since May 1940 the list of acts for which the death penalty might have been imposed in the name of the Polish Underground State had been much wider (for example: treason, espionage, provocation, denunciation or inhuman persecution and harm to the Polish population ${ }^{16}$ ). Severe criticism of "Forbidden Songs" resulted in changes made to the film. In the second version of the story it was clear that a Volksdeutsche woman contributed to a death of a child and therefore was duly punished. However, even in the new version of the film the issue of being a German agent was not resolved in any way.

After the war the problem of betrayal was of utmost importance, not only when referring to the German occupation, but also in the political fight between communist and anti-communist organizations. The category of "traitors of the nation" from the period of German occupation was flexible and started to be used against the enemies of the new communist regime. One of the first decrees of the communist PKWN directly concerned "traitors of the Polish nation". ${ }^{17}$

Not surprisingly the problem of treason reflected in the first post-war premiered movie. It can be said that the "the porridge society" not only tried to deal with the traumatic past, but also to define its boundaries of belonging.

\footnotetext{
${ }^{15}$ AWK, Pierwszy pełny metraż krajowy.

${ }^{16}$ Reprint: KUNERT, Wojskowe sądownictwo specjalne 121; GRABOWSKI, Sądy Kapturowe delegatury Rządu na Kraj; See also: JASIEWICZ, Sądy Kapturowe; GÓRSKI, Polemika; JASIEWICZ, Polemika; PAŚNIK, Regulacja działalności podziemnego sądownictwa.

${ }^{17}$ Edict of the PKWN, 4. 11. 1944, regarding security measures pertaining to traitors to the people (Dz. U. 1944.11.54), cf. Act from 6. 5. 1945 regarding the exclusion of hostile elements from the Polish society (Dz. U. R. P. poz. 96).
}

There was a mass process of verification of nationality and complementary the process of 'Volksdeutsch' rehabilitation. Technically speaking both ended in 1950.18

In view of the political turmoil of 1947, vote fraud and terror used by the communist authorities against political opponents to determine who is or was 'a traitor' had a terribly practical significance. However Buczkowski's film showed only those symptoms of treachery that representatives of the communist authorities and its opponents alike, would probably agree to have them punished. This also might have contributed to the blockbuster success of the movie.

\section{2.}

Already in 1945 Leon Chajn, the deputy head of the Ministry of Justice of the new provisional communist government, ${ }^{19}$ strongly criticized judicial rulings with an anti-Semitic background, stating that "some judges are still trapped in the camp of reaction". ${ }^{20}$

The problem of dealing with anti-Semitism after the Holocaust was so palpable that in the first post-war film "The Forbidden Songs", one could see scenes that depicted problematical relations between Poles and Jews during the German occupation. The scenario presented an "average" tenement house in Warsaw. Just before the above-mentioned execution of a woman, there was a scene showing a Jew being blackmailed by a Polish navy blue policeman. A narrator of "The Forbidden Songs" overtly regrets the fact, stating that "and such people were also among

\footnotetext{
${ }^{18}$ Ended not before the entering into force of the Act from 20.7. 1950 regarding the ending of the sanctions against citizens who declared their belonging to the German people (Dz. U. RP 1950, nr 29, poz. 270).

${ }^{19}$ The Polish Committee of National Liberation.

${ }^{20}$ CHAJn, Sądy a prasa 15.
} 
us". However there was no unambiguous solution of the blackmailing episode in the whole movie. It must have been assumed that the viewer himself should know the most likely course of events.

Nevertheless there were no doubts as to the question if the Polish navy blue police could be condemned on the screens. One of the first acts of law that the communist PKWN issued was a decree liquidating the former navy blue police and setting up its own militia. ${ }^{21}$ According to Art. 1 of the Decree of 15 August 1944 on the termination of the state police, the blue police "served German occupants". Even such a short scene was therefore entirely compatible with legal acts of new authorities.

The blackmailing scene can be considered a good point of departure for the main subject of the other post-war film, "The Border Street" by Alexander Ford. It is no exaggeration to say that the film is still of keen interest especially as an early film wholly devoted to the Holocaus $\mathrm{t}^{22}$ (even before the term started to be widely used to describe Shoah).

The scenario was written in 1946, the year in which the Kielce pogrom occurred, an event that dramatically strained post-war Polish-Jewish relations.

The new cultural policy was related also to the dates of film premieres. In spite of the fact that "The Polish Film Chronicle", the nation-wide newsreel shown in cinemas prior to the main film, informed about the pogrom, ${ }^{23}$ the communist authorities decided to postpone the premiere of Ford's film.

Its content - the tragedy of the Polish Jewry in Warsaw - all of a sudden turned out to be controversial. Anyway for some ambiguous reason

\footnotetext{
${ }^{21}$ Edict of the PKWN, 15. 8. 1944, regarding the disbandment of the State Police (so-called "darkblue police"), Dz. U. z 1944, Nr. 2, poz. 6.

22 PREIZNER, Kamienie na macewie 43.

23 „PKF” 1946, Nr. 22 (15. 7. 1946).
}

"The Border Street" was partly made in Barrandov Studio in Czechoslovakia and the premiere indeed was delayed. ${ }^{24}$ The first post-war comedy was purposefully shown on the screen before "The Border Street".

"The Border Street" depicts the gradual isolation of the community of Polish Jews conducted by the German occupation authorities. The viewers watched some motives already presented in "The Forbidden Songs" (e.g.: the sudden appearance of Volksdeutsche, the hiding of Jews outside the ghetto, the black market between two sides of the city, blackmailing et cetera). New legislation was one of the most important tools to achieve this goal in the occupied territories.

To give evidence of the phenomenon that progressively lead to the Final Solution, ${ }^{25}$ there is even a scene with street megaphones. New regulations were announced and translated into the ordinary language, enforced by some slogans from Nazi propaganda:

"Attention! Attention! Jewish children have escaped from the ghetto. Presence of Jewish children in the Aryan district is unlawful. Who helps Jewish children or feeds them shall be punished by death. The Jewish children spread typhus. [...] The children from the ghetto shall be immediately handed over to police $[\ldots]]^{\prime \prime}$.

In this case there is no need to search for a specific illustration that is more or less associated with the legal iconography. Ford preferred to present (or rather to recall) the audience a much more serious phenomenon: visible results of the introduction of legal regulations imposed on the occupied territory by the Nazis.

For the first time in Polish cinema one could see a reconstruction of a world normatively turned upside down - as it was emphasized by one of the movie protagonists ("This time, ma'am, all

\footnotetext{
${ }^{24}$ Quote A. Ford, in: MADEJ, Kino 182.

${ }^{25}$ BROWNING, Origins of the Final Solution.
} 
decent people live like thieves. And only thieves live peacefully"26).

Indeed, data confirm a change in the structure of crime, which happened due to Nazi amendments to the legal system. The sole fact of closing the ghetto in Warsaw (16 November 1940), which is a central subject of the film, contributed to this change. It is worth recalling that smuggling assured up to $80-90 \%$ of its goods. No wonder that, statistically speaking, from the beginning of the occupation the Jews were punished for committed crimes more often than the Poles. It was a profound reversal of pre-war trends. ${ }^{27}$

Before WW II, according to the Municipal Board estimations, in Warsaw lived 380.567 Jews, which accounted for $29.1 \%$ of all residents of the capital population. ${ }^{28}$ Viewers of "The Border Street" could have watched the creation of the Warsaw ghetto, a migration of the Jewish community to the ghetto, results of the obligation to wear armbands with the Star of David etc.

The gradual ghettoisation of Jews in Warsaw was mainly presented by the visual means of the cinema. However at the same time one can analyze legal solutions that were introduced by the German occupiers, for example the obligation to wear the armband with the Star of David issued by Governor-General Hans Frank that entered into force on 1 December 1939. Then confiscation of large Jewish property, like factories, banks, larger stores etc. (October 1940) and the regulation on the rights of Jewish residence in the General Government (13 September 1940) that ended up in the form of a regulation (15 October 1941) that introduced the death penalty for Jews caught outside the ghetto without a band and a special pass. What is more, the

\footnotetext{
${ }^{26}$ Stanisław Różycki, To jest getto! (Reportaż z interna XX wieku)", 7.12.1941 (quoted in: ENGELKING, GRABOWSKI, Przestępczość 8).

27 ENGELKING, GRABOWSKI, Przestępczość 81.

${ }^{28}$ ENGELKING, LeOCIAK, Getto warszawskie 65.
}

death penalty for people who helped Jews in hiding was also imposed.

In "The Border Street" one can precisely analyze the bunch of "crimes" committed by a girl who stays on the Arian side of the wall, not even knowing that she is Jewish. Assuming that her story continued after October, 1941, she was threatened by the death penalty according to the Nazi "law".

One should underline that there were no ghetto cinematic clichés created before film "The Border Street". Alexander Ford wanted to reconstruct the authenticity of the recent past. The optimistic end of the film (different from the originally planned ending in the script) could be associated with the officially proclaimed optimism of the new ideology. The knowledge of the audience surely made this optimism relative. Main heroes of the film were rather to die not to survive the Ghetto uprising and the afterwards events. In 1946, while analyzing the high level of contemporary crime in Poland, the vicepresident of the Supreme Military Court remarked that "the methods used by the Germans against the Jewish population had to play a special role in moral depravity". ${ }^{29}$ After the war jurisdiction shared this viewpoint. In a case related to the killing of a Jewish worker, the Supreme Court stated: "The awareness and desire to comply with the German authorities expectations, created the whole mentality of Hitler's executioners. Their crimes usually were not the result of natural personal degeneration, but emerged on the background of mental degeneration, acquired under the influence of Hitler's propaganda, and thus arose as a result of submission to the murderous ideology that spread Hitlerism." 30 In spite of all the war atrocities the core of the human nature must have been left good for another ideology. Purely communist

\footnotetext{
${ }^{29}$ MuszKAT, O współczesnej przestępczości 68

${ }^{30}$ Decision of the Supreme Court, 30. 1. 1948 (K 2788/47)
} 
cinematographic work however shall be free of any redundant doubts.

\section{Conclusion}

"The attitude to the law in a totalitarian state and its legal practice was a shock to Europeans formed at the turn of the century" - recalled recently one scholar, adding an anecdote about a Polish intellectual who treated the Stalinist constitution of 1936 in earnest. After the outbreak of WW II he went to the NKWD with the text of the constitution and "demanded the right of asylum and the right to leave the country. $\mathrm{He}$ ended up in Siberia, of course." 31

Paradoxically, not only anecdotes, but also movies captured some essential political and legal problems that today have to be decoded.

Sometimes in order to understand how the more astute viewers were able to discover that what is official may have little or no connection with reality. It is worth considering to what extend this attitude to law became an essential part of the legal culture of the whole region of the 'Bloodlands'. In the cinematographic works of the period of transition one can see a (distorting) mirror of justice. But the worst for cinema was yet to come - with Stalinism - in 1949.

\section{Korrespondenz:}

Jarosław Kuisz

ul. Magiera 8 m. 16, Warszawa 01-873, Polska

jaroslaw_kuisz@wpia.uw.edu.pl

\footnotetext{
31 SAFjan, Prawa Polska 107.
}

\section{Abkürzungen:}

$\mathrm{CPH}$ Czasopismo Prawno-Historyczne

Dz. U. Dziennik Ustaw Rzeczypospolitej Polskiej

NKWD People's Commissariat for Internal Affairs

PKWN Polish Committee of National Liberation

WPP Wojskowy Przegląd Prawniczy

\section{Literatur:}

M. Asimow, S. MAder, Law and Popular Culture: A Course Book (New York 2004).

AWK [A. WAŻYK], Pierwszy pełny metraż krajowy, in: Kuźnica 4 (1947).

J. BARDACH， B. LeŚNODORSKI， M. PIETRZAK， Historia ustroju i prawa polskiego (Warszawa ${ }^{4} 1999$ ).

C. R. BROWNING, The Origins of the Final Solution: The Evolution of Nazi Jewish Policy, September 1939-March 1942 (Lincoln-Yad VashemJerusalem 2004).

M. C. CARNES, Past Imperfect. A History According to the Movies (New York 1995).

L. CHAJN, Sądy a prasa, in: Demokratyczny Przegląd Prawniczy (1945/1) 15.

B. ENGELKING, J. LEOCIAK, Getto warszawskie. Przewodnik po nieistniejącym mieście (Warszawa 2001).

B. EngelKing, J. GrabowsKi, Przestępczość. Żydów w Warszawie 1939-1942 (Warszawa 2010).

G. GóRSKI, Polemika, in: Ład (1986/1).

P. GrabarczyK, T. Stempowski (Hgg.), Prawo w filmie (Warszawa 2009).

W. GRABOWSKI, Sądy Kapturowe delegatury Rządu na Kraj. Przyczynek do działalności Polskiego Państwa Podziemnego, in: CPH 2 (2007) 257-267.

K. KolańCZYK, Prawo niemieckie na „ziemiach przyłączonych", in: Biuletyn Głównej Komisji Badania Zbrodni Niemieckich w Polsce, Bd. 1 (Poznań 1946) 279.

A. W. KUnERT, Wojskowe sądownictwo specjalne ZWZ AK 1940-1944, in: Więź 2 (1981) 121.

I. KURZ (Hg.), Film i historia. Antologia (Warszawa 2008).

K. JASIEWICZ, Sądy Kapturowe w okupowanej Polsce, in: $\operatorname{Lad}(1985 / 40)$.

K. JASIEWICZ, Polemika, in: Ład (1986/1).

W. JASTRZĘBOWSKI, Rządy niemieckiego okupanta w Polsce 1939-1945, in: Państwo i Prawo 2 (1945) 3.

S. MACHURA, P. RoBSON, Law and Film: Introduction, in: Journal of Law and Society 28 (2001) 1-8. 
A. MADEJ, Zjazd filmowy w Wiśle, czyli dla każdego coś przykrego, in: Kwartalnik Filmowy 18 (1997).

A. MADEJ, Kino, władza, publiczność. Kinematografia polska w latach 1944-1949 (Bielsko-Biała 2002).

Mały Rocznik Filmowy 1971. Filmowy serwis prasowy (Warszawa 1972).

A. MisiaK, Cenzura filmowa po zjeździe w Wiśle, in: Kwartalnik Filmowy 43 (2003).

M. MuszKat, O współczesnej przestępczości w Polsce, in: Państwo i Prawo (1946/9-10).

J. PAŚNIK, Regulacja działalności podziemnego sądownictwa w latach 1940-1942 przez Kodeks sądów kapturowych oraz przepisy materialne, in: WPP (1986/4) 432-443.
J. PreizNer, Kamienie na macewie. Holokaust w polskim kinie (Kraków-Budapeszt 2012).

R. A. Rosenstone, History on Film. Film on History (Harlow 2006).

M. SAFJAN, Prawa Polska (Warszawa 2005).

J. ToEPlitz (Hg.), Historia filmu polskiego, Bd. 3 (Warszawa 1974).

M. ZAREMBA, Wielka Trwoga. Polska 1944-1947 (Kraków 2012).

P. ZWIERZCHOWSKI, Zapomniani bohaterowie. O bohaterach filmowych polskiego socrealizmu (Warszawa 2000). 